\title{
The Battle over the Minimum Wage, City by City
}

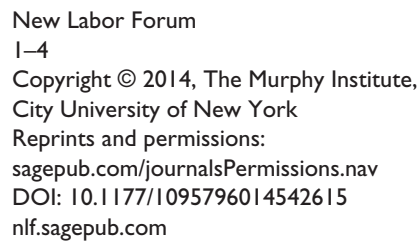

\section{Peter Dreier'}

\author{
Keywords \\ working class, community organizations, corporations, elections, equality, labor, living wage
}

Seattle Mayor Ed Murray used May Day 2014 to announce that business and labor had agreed to a historic plan to raise the minimum wage to $\$ 15$ an hour. Seattle's bold measure is a part of a growing wave of activism and local legislation around the country to help lift the working poor out of poverty. The gridlock in Washington-where Congress has not boosted the federal minimum wage, stuck at $\$ 7.25$ an hour, since 2009-has catalyzed a growing movement in cities and states.

\section{Nineteen states have minimum wages over \$7.25 an hour, and ten states automatically increase their minimum wages with inflation.}

In 2004, San Francisco and Santa Fe, New Mexico were the first two localities to adopt citywide minimum-wage laws, now $\$ 10.74$ and $\$ 10.66$, respectively. Since then, cities from Los Angeles to New York have begun the process of crafting minimum-wage laws with different components. Nineteen states now have minimum wages over $\$ 7.25$ an hour, and ten states automatically increase their minimum wages with inflation. As of June 2014, activists in Idaho, South Dakota, and Alaska were gathering signatures to put minimum-wage hikes on the ballot this year. Their counterparts in Maryland, Illinois, Massachusetts, Minnesota, and Hawaii were pushing state legislators to raise the minimum wages in their states, too.

This upsurge in government-mandated wage hikes has not come about suddenly. It is the result of years of both changing conditions, effective grassroots organizing, and changing public views about the poor.

Throughout his presidency, Ronald Reagan often told the story of a so-called "welfare queen" in Chicago who drove a Cadillac and had ripped off $\$ 150,000$ from the government using eighty aliases, thirty addresses, a dozen Social Security cards, and four fictional dead husbands. Journalists searched for this welfare cheat and discovered that she did not exist. To show he was not a tax-and-spend Democrat, Bill Clinton campaigned in 1992 to "end welfare as we know it," in part by "making work pay." Congress enacted so-called welfare reform in 1996, limiting the time people can receive assistance.

Although liberals understandably decried this approach, it ironically helped shift public opinion and stereotypes about the poor. According to historians and sociologists, the public distinguishes between the "undeserving" and the "deserving" poor. The latter are viewed as more responsible, hard-working, and victims of circumstances beyond their control. Increasingly, Americans came to view low-income people as the "working poor," a group considered more sympathetic than the so-called "welfare poor."

In the $1990 \mathrm{~s}$, the mainstream news media began to pay more attention to the working poor, while academics and journalists expressed growing concern about the "Walmart-ization" of the

'Occidental College, Los Angeles, CA, USA

\section{Corresponding Author:}

Peter Dreier, dreier@oxy.edu 
economy - the growing number of low-wage jobs with few benefits. In 1999, Barbara Ehrenreich published an article in Harper's magazine that two years later became her best-selling book, Nickel and Dimed: On (Not) Getting By in America, recounting her experiences toiling alongside hard-working low-wage employees who could not make ends meet. But it took effective grassroots organizing to translate these changing sentiments into public policy.

The federal wage rarely came close to putting workers above the poverty line. In 1994, it had sunk to $\$ 4.25$ - or $\$ 7.31$ in today's dollars. Congress had not raised the threshold in three years, despite rising living costs. Frustrated by congressional inaction, a coalition of community organizations, religious congregations, and labor unions in Baltimore - called BUILDmobilized a successful grassroots campaign to pass the nation's first municipal "living wage" law in 1994. It required companies with municipal contracts and subsidies to pay employees decently. The movement was motivated not only by stagnating wages but also by the city government's efforts to contract public services to private firms paying lower wages and benefits than those that prevailed in the public sector.

\section{The living wage movement was one of the most successful, if unheralded, community organizing efforts over the past two decades.}

The idea quickly caught fire. Since then, about 120 cities have adopted laws that establish a wage floor, from $\$ 9$ to $\$ 16$ an hour, mostly for businesses that receive contracts or subsidies from local governments. Unions and community organizing groups-particularly ACORNplayed key roles in mounting these campaigns. The living wage movement was one of the most successful, if unheralded, community organizing efforts over the past two decades. By injecting the phrase "living wage" into the public debate, it helped shift public opinion because it implicitly suggests that people who work fulltime should not live in poverty.

Likewise, the Occupy movement, which began in New York City in September 2011 and quickly spread to cities and towns around the country, changed the national conversation. At kitchen tables, in coffee shops, in offices and factories, and in newsrooms, Americans began talking about economic inequality, corporate greed, and how America's super-rich have damaged our economy and our democracy.

Even after local officials pushed Occupy protesters out of parks and public spaces, the movement's excitement and energy were soon harnessed and co-opted by labor unions, community organizers, and progressive politicians like Seattle's Murray, New York's de Blasio, newly elected mayors Betsy Hodges of Minneapolis and Marty Walsh of Boston, and many others who embraced the idea of using local government to address income inequality and low wages.

Growing activism by low-wage workers around the country - assisted primarily by the SEIU, UNITE HERE, and the United Food and Commercial Workers union-has put a public face on and sense of urgency over the plight of America's working poor. Over the past two years, workers across the country at fast-food chains such as McDonald's, Taco Bell, and Burger King have gone on strike and demanded a base wage of at least $\$ 15$ per hour. Walmart workers have engaged in one-day work stoppages and civil disobedience as part of an escalating grassroots campaign to demand that the nation's largest private employer pay its workers at least $\$ 25,000$ a year, thousands more than a full-time worker making $\$ 10.10$ per hour would earn.

These protests triggered increasing media coverage, including brilliant put-downs on The Daily Show with Jon Stewart and The Colbert Report of the conservative arguments against the minimum wage. Progressive think tanks have produced reports that gave substance to growing public outrage about the widening income divide and the plight of the working poor. According to the National Employment Law Project (NELP), the majority of new jobs created since 2010 pay just $\$ 13.83$ an hour or less. Last year, a NELP study revealed that the low wages paid to employees of the ten largest fast-food chains cost taxpayers an estimated $\$ 3.8$ billion a year by forcing employees to rely 
on public assistance to afford food, health care, and other basic necessities. A study released in March by the Institute for Policy Studies found that the bonuses handed to 165,200 executives by Wall Street banks in 2013-totaling $\$ 26.7$ billion - would be enough to more than double the pay for all 1,085,000 Americans who work full-time at the current federal minimum wage of $\$ 7.25$ per hour.

The reality of widening inequality and declining living standards, the activism of Occupy movement radicals and low-wage workers, and increasing media coverage of these matters has changed public opinion. A national survey by the Pew Research Center conducted in January 2014 found that 60 percent of Americans - including 75 percent of Democrats, 60 percent of independents, and even 42 percent of Republicans - think the economic system unfairly favors the wealthy. The poll discovered that 69 percent of Americans believe the government should do "a lot" or "some" to reduce the gap between the rich and everyone else. Nearly all Democrats (93 percent) and large majorities of independents (83 percent) and Republicans (64 percent) said they favor government action to reduce poverty. Over half (54 percent) of Americans support raising taxes on the wealthy and corporations to expand programs for the poor, compared with one-third (35 percent) who believe lowering taxes on the wealthy to encourage investment and economic growth would be the more effective approach. Overall, 73 percent of the public_including 90 percent of Democrats, 71 percent of independents, and 53 percent of Republicans-favors raising the federal minimum wage from its current level of $\$ 7.25$ an hour to $\$ 10.10$ an hour.

\section{Seventy-three percent of the public favors raising the federal minimum wage to $\$ 10.10$ an hour.}

Progressives have clearly won the moral argument. Americans believe that people who work should not live in poverty. So business groups have to resort to trying to persuade the public that raising the federal minimum wage - or adopting a living wage or minimum-wage plan at the local level-will hurt the economy. Business lobby groups and business-funded think tanks - including the U.S. Chamber of Commerce and its local affiliates, the National Restaurant Association, the American Legislative Exchange Council, the Employment Policies Institute (an advocacy group funded by the restaurant industry), and other industry trade associations - typically dust off studies funded by business groups warning that firms employing low-wage workers will be forced to close, hurting the very people the measure was designed to help.

But such dire predictions have never materialized. That is because they are bogus. In fact, many economic studies show that raising the minimum wage is good for business and the overall economy. Why? Because when lowwage workers have more money to spend, they spend it, almost entirely in the local community, on basic necessities like housing, food, clothing, and transportation. When consumer demand grows, businesses thrive, earn more profits, and create more jobs. Economists call this the "multiplier effect." Moreover, most minimum-wage jobs are in "sticky" (immobile) industries - such as restaurants, hotels, hospitals and nursing homes, and retail stores - that cannot flee.

In their new book, When Mandates Work: Raising Labor Standards at the Local Level, economists Michael Reich and Ken Jacobs of the University of California at Berkeley summarize the findings of research on the impact of local minimum-wage laws. They discovered there are no differences in employment levels between comparable cities with and without living wage laws. In doing so, they showed that business lobby groups are crying wolf when they claim these laws drive away business and kill jobs.

All this local activism and shifts in public opinion have had a significant political impact. Mainstream politicians of both parties increasingly feel compelled to discuss the nation's growing inequality and the greed of the superrich. In his January 2013 State of the Union address, Obama proposed raising the federal minimum wage to $\$ 9$ an hour. "Even with the tax relief we've put in place, a family with two kids that earns the minimum wage still lives 
below the poverty line. That's wrong," Obama said. The following November, he embraced a bill sponsored by Senator Tom Harkin of Iowa and Representative George Miller of California to lift the federal minimum to $\$ 10.10$ an hour.

In the 2012 Republican presidential primaries, some GOP candidates attacked Mitt Romney for being an out-of-touch crony capitalist. In his campaign against Obama, Romney opposed a hike in the minimum wage. But this May, Romney urged Republicans to endorse a $\$ 10.10$ minimum wage, arguing it would help GOP candidates "convince the people who are in the working population, particularly the Hispanic community, that our party will help them get better jobs and better wages."

It is unlikely that either Obama's or Romney's change of heart was the result of key economic advisers persuading them that a bigger wage boost was needed to reduce poverty and stimulate the economy. Both of those things are true and surely entered into their thinking, but the major impetus was political. They were responding to the growing protest movement, public opinion polls, and election outcomes reflecting widespread sentiment that people who work full-time should not be mired in poverty.

Despite public support for a federal wage hike, the Republicans in Congress have refused to budge. In March 2013, for example, all 227
House Republicans (plus 6 Democrats) voted against the Harkin-Miller bill (184 Democrats voted yes). In anticipation of the 2014 midterm elections, Democrats, unions, and other progressives view the growing momentum for a minimum-wage hike as a way to pressure Congressional Republicans facing tough reelection campaigns, hoping to persuade them to support an increase.

Whether they do or do not, the movement to raise wages will continue to gain momentum at the local and state levels. It is a heartening reminder that democracy - the messy mix of forces that typically pits organized people versus organized money-still can work.

\section{Declaration of Conflicting Interests}

The author(s) declared no potential conflicts of interest with respect to the research, authorship, and/or publication of this article.

\section{Funding}

The author(s) received no financial support for the research, authorship, and/or publication of this article.

\section{Author Biography}

Peter Dreier teaches politics at Occidental College and is the author of The 100 Greatest Americans of the 20th Century: A Social Justice Hall of Fame (Nation Books, 2012). 